\title{
Implementasi Model Kesuksesan Sistem Informasi DeLone And McLean Terhadap Sistem Pembelajaran Berbasis Aplikasi Zoom Di Saat Pandemi Covid-19
}

Syarif Hidayatullah ${ }^{1}$, Umu Khouroh ${ }^{2}$, Irany Windhyastiti ${ }^{3}$, Ryan Gerry Patalo ${ }^{4}$, Abdul Waris ${ }^{5}$

${ }^{1234}$ Fakultas Ekonomi dan Bisnis Universtas Merdeka Malang

${ }^{5}$ Politeknik Negeri Malang

\begin{tabular}{l}
\hline Info Artikel \\
\hline Riwayat Artikel \\
Diterima: $22-04-2020$ \\
Disetujui: $30-04-2020$
\end{tabular}

$\underline{\text { Kata Kunci }}$

Kualitas Sistem Informasi;

Kualitas Layanan;

Kepuasan Pengguna;

Net Benefit;

COVID-19;

Corresponding Author

Syarif Hidayatullah

Fakultas Ekonomi dan Bisnis

Universtas Merdeka Malang

Tel. +62 82141415790

syarif_ok@yahoo.com

\begin{abstract}
ABSTRAK
Investasi dalam sistem informasi saat ini memiliki dampak yang signifikan terhadap aspek yang multidimensional, seperti perbankan, pendidikan, kepariwisataan dan lainnya. Sistem informasi memainkan peran penting dalam memberikan pelayanan yang lebih baik dan keunggulan kompetitif. Dalam dunia pendidikan, di masa saat ini kondisi dunia dan Indonesia mengalami pendemi COVID19 sehingga himbauan pemerintah yang menyatakan bekerja dari rumah (work from home), social distancing serta penyesuaian sistem kerja bukan berarti pelayanan publik dan pembelajaran dihentikan, namun semua aktivitas dilakukan dengan bantuan teknologi informasi atau secara online. Salah satu media atau aplikasi yang biasa digunakan untuk sistem pembelajaran adalah aplikasi zoom. Penelitian ini merupakan explanatory research, lokasi penelitian ini dilakukan di kota Malang Jawa Timur. Populasi dalam penelitian ini adalah semua orang yang pernah menggunakan aplikasi zoom dalam beraktivitas terutama bidang pendidikan dengan jumlah sampel 180 responden. Pengumpulan data dengan penyebaran kuesioner, karena kondisi pandemic Covid-19 dengan pentingnya menerapkan Social Distancing maka penyebaran kuesioner dilakukan secara online. Teknik analisis data menggunakan Analisis Statistik Deskriptif, Analisis data menggunakan SEM dan Pengujian Hipotesis. Hasil dari penelitian ini system quality berpengaruh positif terhadap User Satisfaction, Information Quality berpengaruh positif terhadap User Satisfaction, Service Quality berpengaruh positif terhadap User Satisfaction dan User Satisfaction berpengaruh positif terhadap Net Benefit.
\end{abstract}

\section{PENDAHULUAN}

Perkembangan teknologi informasi membuat orang menjadi berfikir bagaimana membuat keputusan tepat dan cepat atau efektif dan efisien di semua aktivitas yang dilakukan. Aplikasi sistem teknologi informasi sangat diharapkan dapat bermanfaat untuk membantu aktivitas karena sistem informasi yang didukung teknologi informasi dapat mendukung 
pengambilan keputusan serta dapat membawa keberhasilan kegiatan yang dilakukan, seperti pada bidang bisnis, ekonomi, social politik maupun bidang pendidikan (James A. O'Brien \& Marakas, 2017).

Investasi dalam sistem informasi saat ini memiliki dampak yang signifikan terhadap aspek yang multidimensional dalam artian mencakup berbagai aspek dalam kehidupan berbisnis seperti perbankan, pendidikan, kepariwisataan dan lainnya. Hal ini dikarenakan sistem informasi memainkan peran penting dalam memberikan pelayanan yang lebih baik dan keunggulan kompetitif sehingga diperlukan adanya inovasi dalam pemasaran atau disebut entrepreneurial marketing (Hidayatullah et al., 2019). Hal Ini merupakan tantangan bagi organisasi untuk terus meningkatkan kesuksesan sistem informasi yang dimilikinya dan terus memonitoring apa saja yang perlu diperbaiki dan ditambahkan agar pengguna sistem bisa puas (Jaafreh, 2017) .

Saat ini ledakan penggunaan sistem informasi melonjak sangat pesat, kecepatan informasi sangat amat diperlukan bagi semua kegiatan terlebih lagi dalam kondisi Pandemi Covid-19. Himbauan pemerintah yang menyatakan bekerja dari rumah (work from home), social distancing serta penyesuaian sistem kerja bukan berarti pelayan public dan pembelajaran dihentikan, namun semua aktivitas dilakukan dengan bantuan teknologi informasi atau secara online. Hal ini juga berlaku untuk dunia pendidikan dengan dihapuskannya Ujian Nasional, belajar di rumah melalui aplikasi tertentu, kuliah daring, bimbingan dan seminar daring merupakan contoh pelayanan bidang pendidikan yanng mempercepat penerapan pendidikan era revolusi 4.0. Dari beberapa kasus diatas menuntut peran teknologi dalam bidang pendidikan di tengah pandemi covid-19, para tenaga pendidik dan peserta didik diharapkan dapat menyesuaikan diri dan memanfaatkan teknologi.

Dengan diberlakukannya kebijakan physical distancing yang menjadi dasar dalam pelaksanaan sistem belajar dari rumah, dengan pemanfaatan teknologi informasi yang berlaku secara mendadak, hal ini membuat pendidik dan peserta didik sangat kaget termasuk orang tua bahkan semua orang yang berada dalam rumah. Pembelajaran dengan sistem teknologi informasi memang sudah diberlakukan dalam beberapa tahun terakhir dalam sistem pendidikan di Indonesia. Namun, pembelajaran daring yang berlangsung sebagai kejutan dari pandemi Covid-19, membuat kaget hampir di semua lini, dari kabupaten/kota, provinsi, pusat bahkan dunia internasional.

Dengan adanya program working dan learning from home terkait adanya pandemi Virus Corona permintaan untuk pasang internet di rumah meningkat. Jumlah pelanggan baru pada Maret meningkat 30 persen sampai dengan 40 persen dibandingkan dengan bulan sebelumnya (www.cnn.indonesia.com). Demikian halnya dengan aplikasi rapat yang ada, seperti aplikasi zoom pada 26 Maret 2020, Aplikasi Zoom mencatatkan sebanyak 257,853 pengguna, di mana pada minggu sebelumnya 19 Maret 2020, aplikasi ini berada pada angka 91.030 orang. Di sisi lain, aplikasi posisi Zoom diikuti oleh Skype di posisi kedua yang mencatatkan 71.155 pengguna, dengan indikasi mengalami kenaikan sebesar 8,02 persen kenaikan dari pengguna sebelumnya yang mencapai 65.875 orang. Untuk aplikasi selanjutnya, Hangouts Meet mengalami peningkatan trafik yang cukup signifikan lewat penggunaan di masyarakat pada 19 Maret 2020 mencapai 7.917 yang meningkat pada 26 Maret 2020 sebesar 10.454 pengguna, dengan kenaikan sebesar 32, 14 persen. (www.Teknologi.bisnis.com/ penggunaan-aplikasi-conference, 17 April 2020)

Dengan jumlah pengguna aplikasi konferensi yang tidak sedikit pada dunia pendidikan, maka peneliti merasa tertarik untuk melakukan penelitian guna mengetahui pengaruh kualitas sistem, kualitas informasi dan kualitas pelayanan terhadap kepuasan pengguna aplikasi zoom serta keuntungannya bagi pengguna aplikasi berbasis konferensi zoom. Penelitian ini mengacu pada penelitian sebelumnya yang dilakukan oleh Muhammad irfan (2019) dengan judul pengaruh kualitas sistem, kualitas informasi, kualitas pelayanan terhadap net benefit pemakaian sistem pembayaran BRI dan penelitian yang dilakukan oleh Ratri Saras (2016) 
dengan judul Analisa Faktor-Faktor yang mempengaruhi Penggunaan e-learning Moodle oleh guru SMK N 2 Yogyakarta dengan pendekatan TAM

\section{Sistem Infomasi Manajemen}

Menurut (Arbie, 2000) Sistem adalah setiap kumpulan dari komponen atau sub-sistem yang berinteraksi untuk mencapai suatu tujuan tertentu. Informasi diartikan sebagai hasil pengolahan data yang digunakan untuk suatu keperluan, sehingga penerimanya akan mendapat rangsangan untuk melakukan tindakan. Data adalah fakta yang jelas lingkup, tempat dan waktu-nya. Data diperoleh dari sumber data primer atau sekunder dalam bentuk berita tertulis atau sinyal elektronis (Riset \& Dan, 2007).

\section{Model Kesuksesan Sistem Informasi DeLone dan McLean}

Merupakan suatu model penelitian yang dikembangkan dalam mengukur kesuksesan suatu sistem informasi berdasarkan penelitian yang dilakukan oleh DeLone dan McLean (1992). Pada model DeLone dan McLean atau yang lebih dikenal dengan D\&M IS Success ini dimensi-dimensi kesuksesannya yang diukur semuanya saling berkaitan.

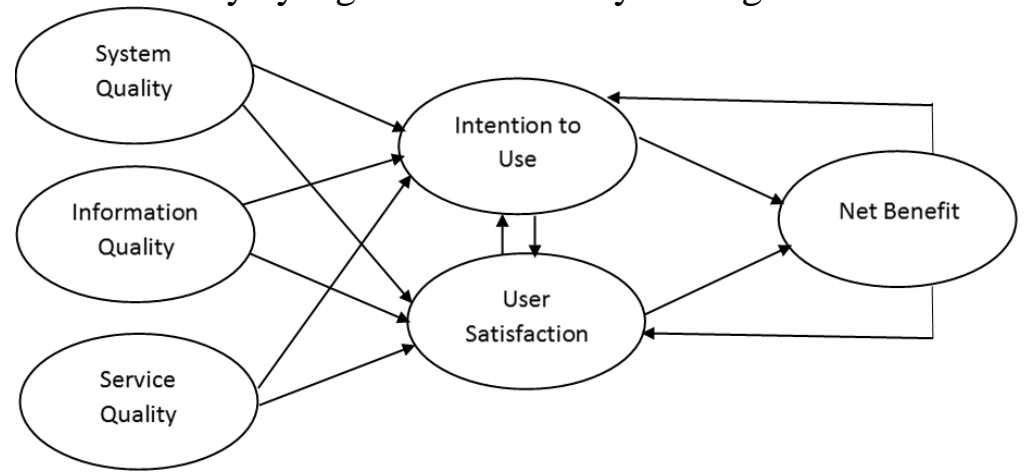

\section{Kualitas Sistem}

Gambar 1 : Model Kesuksesan Informasi DeLone dan McLean (2003)

Kualitas sistem adalah gabungan atau kombinasi dari hardware serta software didalam suatu sistem informasi. Kualitas dari sistem juga merupakan suatu karakteristik sistem informasi yang selalu melekat tentang sistem itu sendiri seperti kemudahan penggunaan sistem, keandalan suatu sistem, serta kecanggihan sistem dan waktu merespon sistem (Delone \& Mclean, 2003).

\section{Kualitas Informasi}

Kualitas informasi adalah output dari sistem informasi yang digunakan. kualitas informasi bisa berbentuk hasil output informasi tersebut seperti informasi yang mudah dimengerti, akurasi yang baik, kelengkapan yang cukup, dan ketepatan (Delone \& Mclean, 2003). Sistem aplikasi dalam penggunaan teknologi informasi harus bisa menyediakan suatu informasi untuk dapat mendukung pengambilan keputusan bagi penggunanya (Widodo, Putranti, \& Nurchayati, 2016).

\section{Kualitas pelayanan}

Kualitas pelayanan merupakan suatu keharusan yang harus segera dilakukan agar dapat bertahan dan tetap mendapat kepercayaan, kualitas pelayanan dapat diartikan kualitas yang mendukung pengguna sistem atau aplikasi. Mengetahui Kualitas pelayanan (service quality) dapat dilakukan dengan cara membandingkan persepsi pengguna sistem atas pelayanan yang diterima dengan atau peroleh dengan kenyataan yang sesungguhnya di harapkan atau inginkan dari atribut-atribut yang ada (Putro, Semuel, Ritzky, \& Brahmana, SE., 2014)

\section{Kepuasan Pengguna}

Menurut Stanton (1994), kepuasan konsumen dapat ditentukan dengan cara membandingkan hasil yang diperoleh (produk atau jasa) dengan hasil berdasarkan pengalaman dengan menggunakan produk atau jasa tersebut. Sedangkan Kotler (2002) mendefinisikan kepuasan pengguna sebagai suatu tingkat perasaan seorang pengguna sistem sebagai hasil perbandingan antara harapan dengan hasil yang diperoleh. Jika kinerja suatu 
produk atau jasa memenuhi ekspetasi dari pengguna maka tingkat kepuasan pengguna dapat dikatagorikan tinggi, sedangkan jika kinerja produk atau jasa tidak memenuhi ekspetasi pengguna maka tingkat kepuasan konsumen dapat dikatakan rendah. Lalu jika hasil yang diperoleh melebihi harapan pengguna, tentu pengguna akan merasa sangat puas (highly satisfied).

\section{Kerangka Konsep Penelitian}

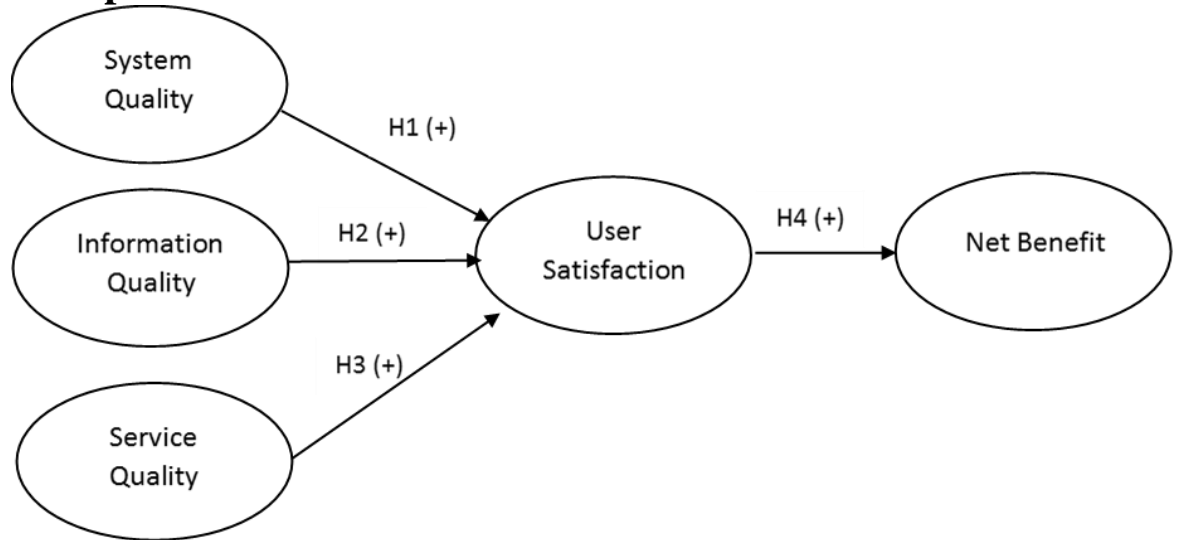

Gambar 2 : Kerangka Konseptual Penelitian

Sumber : Model Kesuksesan Informasi DeLone dan McLean, diolah (2019)

\section{METODE}

Penelitian untuk menguji sejauh mana system quality, Information quality dan service quality pengaruhnya terhadap User Satisfaction serta Net Benefit. Penelitian ini merupakan explanatory research, penelitian ini berlokasi di kota Malang Jawa Timur. Populasi dalam semua mahasiswa yang pernah melakukan sistem pembelajaran menggunakan aplikasi Zoom di Kota Malang. Karena jumlah populasi tidak diketahui maka jumlah sampel ditentukan dengan menggunakan pendapat (Hair, Jr, 2015) dimana apabila jumlah populasi tidak diketahui maka penarikan sampel dilakukan dengan menggunakan ukuran 5-10 dikalikan dengan item pertanyaan, karena jumlah item pertanyaan 18 sehingga jumlah sampel dalam penelitian ini $(10 \times 18=180)$ responden. Pengumpulan data dengan penyebaran kuesioner, karena kondisi pandemic Covid-19 dengan pentingnya menerapkan Social Distancing maka penyebaran kuesioner dilakukan secara online. Teknik analisis data menggunakan Analisis Statistik Deskriptif, Analisis data menggunakan SEM dan Pengujian Hipotesis. Adapun definisi operasional penelitian ini dapat dilihat pada tabel 1 berikut ini :

Tabel 1 : Definisi Operasional Variabel Penelitian

\begin{tabular}{llll}
\hline No & \multicolumn{1}{c}{ Variabel } & No & \multicolumn{1}{c}{ Indikator } \\
\hline 1 & Kualitas Sistem & 1 & Mudah Dipelajari \\
performa dari sistem, yang merujuk & 2 & Mudah di akses \\
pada seberapa baik kemampuan & 3 & Terkoneksi dengan Cepat \\
perangkat keras, perangkat lunak, & 4 & Dapat diandalkan \\
kebijakan, prosedur dari sistem & & \\
$\begin{array}{l}\text { informasi dapat menyediakan } \\
\text { informasi kebutuhan pengguna. }\end{array}$ & & \\
Kualitas Informasi & 5 & Informasi Penggunaan lengkap \\
kelengkapan informasi (completeness), & 6 & Aplikasi yang mudah dipahami \\
mudah difahami (ease understanding), & 7 & Informasi yang ada akurat \\
keakuratan informasi (accuracy) dan \\
relevan (relevance).
\end{tabular}




\begin{tabular}{|c|c|c|c|}
\hline No & Variabel & No & Indikator \\
\hline \multirow[t]{5}{*}{3} & Kualitas Pelayanan & 9 & Pemakaian Tidak ada kendala \\
\hline & Kualitas pelayanan didefinisikan & 10 & Adanya jaminan keamanan pengguna \\
\hline & dalam penelitian ini sebagai penilaian & 11 & Metode pembayaran dalam upgrade \\
\hline & yang dipersepsikan dari hasil & 12 & Masalah dalam aplikasi cepat \\
\hline & $\begin{array}{l}\text { membandingkan harapan pengguna } \\
\text { terhadap pelayanan yang diterimanya. }\end{array}$ & & terlayani \\
\hline \multirow[t]{3}{*}{4} & Kepuasan Pengguna & 13 & Puas terhadap aplikasi Zoom \\
\hline & Merupakan respon dan umpan balik & 14 & Berniat menggunakan aplikasi lagi \\
\hline & $\begin{array}{l}\text { yang dimunculkan pengguna setelah } \\
\text { memakai sistem informasi. }\end{array}$ & 15 & $\begin{array}{l}\text { Tampilan Aplikasi sudah efektif dan } \\
\text { efisien }\end{array}$ \\
\hline \multirow[t]{4}{*}{8.} & Net Benefit & 16 & Aplikasi sudah memberikan manfaat \\
\hline & Adalah efek yang ditimbulkan dari & & lebih \\
\hline & $\begin{array}{l}\text { penggunaan sistem informasi pada } \\
\text { individu, kelompok, organisasi, }\end{array}$ & 17 & $\begin{array}{l}\text { Aplikasi memudahkan transfer ilmu } \\
\text { pengetahuan }\end{array}$ \\
\hline & $\begin{array}{l}\text { industri, masyarakat, dll, hal ini } \\
\text { termasuk dampak individu, manfaat } \\
\text { dari pelanggan dan masyarakat serta } \\
\text { organisasi. }\end{array}$ & 18 & $\begin{array}{l}\text { Aplikasi dapat menampung lebih } \\
\text { dari } 50 \text { pengguna secara bersamaan }\end{array}$ \\
\hline
\end{tabular}

Sumber : Berbagai artikel, diolah (2020)

\section{HASIL DAN PEMBAHASAN}

Sejumlah 180 responden penelitian yang berpartisipasi menjawab kuisioner penelitian ini dan mengembalikan secara online. Adapun hasil dan pembahasan dari penelitian ini dapat disajikan sebagai berikut:

\section{Demographic Statistic}

Tabel 2. Demographic Profil

\begin{tabular}{llcr}
\hline Item & Optional & Frequency & Percentag \\
\hline Gender & Laki laki & 94 & 49,47 \\
& Perempuan & 86 & 45,26 \\
\hline Income & 0-1 Juta & 77 & 40,53 \\
& 1-1,5 juta & 65 & 34,21 \\
& 1.5 - 2 juta & 36 & 18,95 \\
& Lebih dari 2 Juta & 2 & 1,05 \\
& & & \\
\hline Lama & 0 - 15 menit & 76 & 40 \\
menggunakan & 15 - 30 Menit & 21 & 11,05 \\
aplikasi zoom & 30 - 45 menit & 64 & 33,68 \\
& lebih dari 45" & 19 & 10 \\
\hline
\end{tabular}

Sumber : Data Primer, diolah (2020)

\section{Analisis Model Struktural}

Model struktural pada penelitian ini dapat dilihat pada Gambar 3. Menurut Santoso (2012) menyatakan bahwa kriteria utama dari pengujian keseluruhan model (overall model fit) adalah pada perhitungan Chi-Square (CMIN). Hasil pengujian tersebut dapat dilihat pada output AMOS seperti pada Tabel 3. 


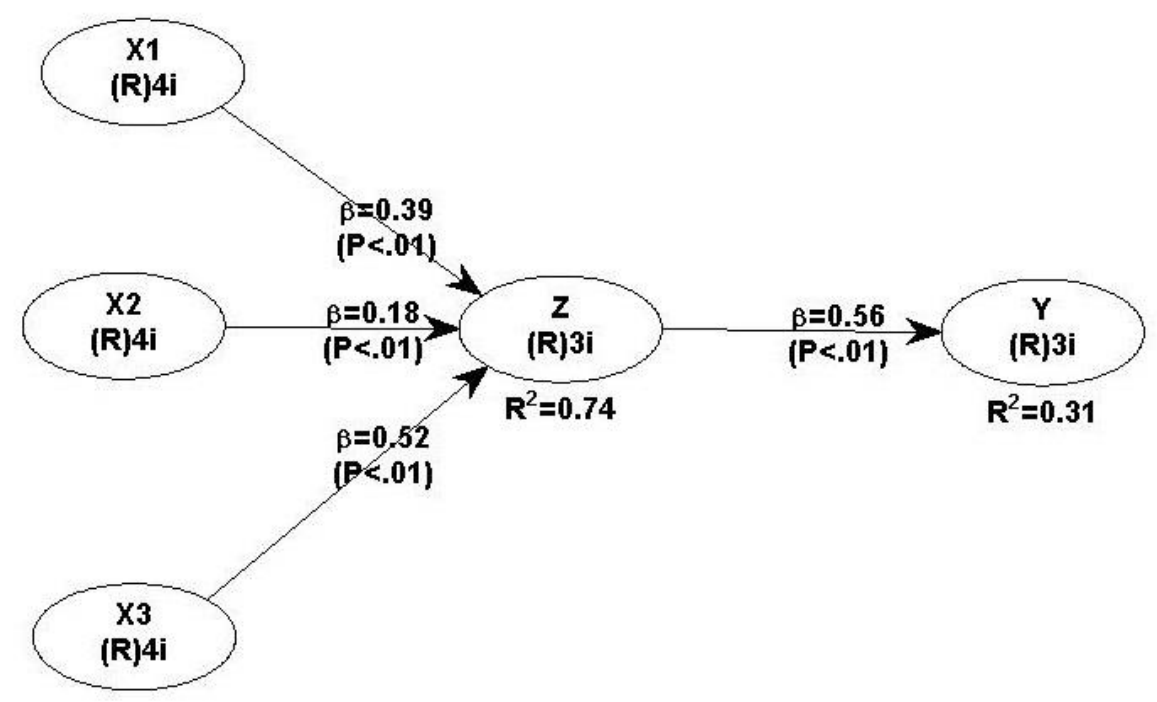

Gambar 3. Output SEM dengan menggunakan AMOS

Sumber : Data Primer, diolah (2020)

Tabel 3 : Output SEM dengan menggunakan AMOS

\begin{tabular}{llccc}
\hline \multicolumn{1}{c}{ Konstruk } & & & $\mathbf{R}^{\mathbf{2}}$ & Sig. \\
& $\boldsymbol{\beta}$ & $\mathbf{P}$ Values & & \\
\hline System quality $\rightarrow$ User Satisfaction & 0,39 & $\mathrm{P}<0,01$ & & Signifikan \\
Information quality $\rightarrow$ User Satisfaction & 0,18 & $\mathrm{P}<0,01$ & 0,74 & Signifikan \\
Service quality $\rightarrow$ User Satisfaction & 0,52 & $\mathrm{P}<0,01$ & & Signifikan \\
User Satisfaction $\rightarrow$ Net Benefit & 0,56 & $\mathrm{P}<0,01$ & 0,31 & Signifikan \\
& & &
\end{tabular}

Sumber: Data Primer, diolah (2020)

\section{Uji Hipotesis :}

\section{Pengaruh system quality terhadap User Satisfaction}

Hipotesis pertama (H1) penelitian ini yang menyatakan terdapat pengaruh system quality terhadap User Satisfaction didukung dan terbukti secara statiktik hal ini dilihat kunstruk eksogen system quality memiliki pengaruh positif $(0,39)$ serta dari nilai p-values 0,01 , artinya bahwa apabila kualitas sistem maka kepuasan pengguna sistem akan meningkat pula. Hal ini menunjukan pula jika kualitas sistem yang ada pada aplikasi zoom baik akan berdampak pada kepuasan mahasiswa pengguna aplikasi juga akan baik (Iivari, 2005). Implikasi dari hipotesis ini, mahasiswa pengguna aplikasi zoom merasa sistem yang ada pada aplikasi zoom sangat simple sederhana dan sangat mudah untuk mahasiswa dipelajari, selain itu aplikasi zoom juga mudah diakses, cepat dalam setiap perpindahan layer yang ada di aplikasi, dan dapat diandalkan untuk kegiatan meeting atau sistem pembeljaran sehingga mahasiswa tidak memerlukan keahlian yang khusus banyak untuk menggunakannya. Hasil Penelitian ini mendukung model yang dikembangkan oleh (DeLone \& McLean, 2003), dan sesuai dengan penelitian yang dilakukan oleh (Iivari, 2005), (Saputro et al., 2016) (Rakhmadian et al., 2017), serta (Urbach \& Müller, 2012)

\section{Pengaruh Information Quality terhadap User Satisfaction}

Hipotesis ke dua $(\mathrm{H} 2)$ penelitian ini yang menyatakan terdapat pengaruh Information quality terhadap User Satisfaction didukung dan terbukti secara statiktik hal ini dilihat kunstruk eksogen information quality memiliki pengaruh positif $(0,52)$ serta dari nilai pvalues 0,01 , Artinya pemakaian aplikasi zoom oleh responden selama ini tidak terdapat kendala yang berarti, adanya jaminan keamanan dalam meeting, sistem pembayaran bila 
upgrade aplikasi juga sangat mudah serta masalah yang ada biasanya selalu cepat terselesaikan. Hasil penelitian ini menginformasikan dengan semakin lengkapnya informasi yang ada, mudahnya dalam pemahaman fitur, serta relevan atau keakuratan yang ada pada aplikasi zoom, maka akan semakin tinggi pula kepuasan pengguna aplikasi zoom. Hasil penelitian ini mendukung model yang dikembangkan oleh (DeLone \& McLean, 2004), dan sesuai dengan penelitian yang dilakukan oleh (Wang, 2008) dan (Rachmawati et al., 2019) (Mardiana et al., 2015).

\section{Pengaruh Service Quality terhadap User Satisfaction}

Hipotesis ke tiga (H3) penelitian ini yang menyatakan terdapat pengaruh service quality terhadap User Satisfaction didukung dan terbukti secara statiktik hal ini dilihat kunstruk eksogen service quality memiliki pengaruh positif $(0,18)$ serta dari nilai p-values 0,01 , artinya responden selama ini puas terhadap penggunaan aplikasi zoom, mereka juga berniat untuk menggunakan aplikasi zoom dilain kesempatan serta tampilan yang ada pada aplikasi zoom sudah sangat efektif dan efisien walaupin masih sederhana. Hasil penelitian ini menginformasikan dengan bagusnya pelayanan yang ada dalam penggunaan aplikasi zoom, maka akan semakin tinggi pula kepuasan pengguna aplikasi zoom. Hasil penelitian ini mendukung model yang dikembangkan oleh (DeLone \& McLean, 2004), dan sesuai dengan penelitian yang dilakukan oleh (Ojo, 2017) dan (Bernroider, 2008) .

\section{Pengaruh User Satisfaction terhadap Net Benefit}

Hipotesis ke empat (H4) penelitian ini yang menyatakan terdapat pengaruh User Satisfaction terhadap Net Benefit didukung dan terbukti secara statiktik hal ini dilihat kunstruk eksogen user satisfaction memiliki pengaruh positif $(0,56)$ serta dari nilai pvalues 0,01, artinya aplikasi zoom yang ada sudah memberikan manfaat lebih bagi responden, aplikasi zoom dalam pendidikan juga sudah dinilai memudahkan transfer ilmu pengetahuan serta responden merasa mendapat manfaat lebih karena aplikasi zoom dapat menampung sampai 100 partisipan sehingga rapat atau kuliah yang ada dengan kapasitas besar tidak dilakukan berkali kali. Hasil penelitian ini menginformasikan dengan bagusnya pelayanan yang ada dalam penggunaan aplikasi zoom, maka akan semakin tinggi pula kepuasan pengguna aplikasi zoom. Hasil penelitian ini mendukung model yang dikembangkan oleh (Liao et al., 2003), dan sesuai dengan penelitian yang dilakukan oleh (Febrianto, 2018) (Mikić et al., 2000).

Dari hasil pembahasan yang telah disampaikan sebelumnya, dalam suasana pandemi covid-19 saat ini mau tidak mau, suka atau tidak suka atau bisa atau tidak bisa mengaruskan semua sector harus bertahan dengan kondisi yang ada, tidak terlepas juga pada dunia pendidikan. Pengguna aplikasi konferensi video zoom melonjak drastis selama pandemi virus corona yang terjadi nyaris di seluruh penjuruh dunia. Zoom mencatatkan lebih dari 200 juta pengguna pada bulan Maret dari sebelumnya hanya maksimum sebanyak 10 juta pengguna. Lebih dari 90.000 sekolah di 20 negara menggunakan layanan konferensi video untuk melakukan kelas jarak jauh. Walau dikatakan aplikasi zoom masih belum aman namun dalam dunia pendidikan yang tujuan penyebaran ilmu zoom masih dapat dikatagorikan aplikasi yang paling sering digunakan. Berdasarkan hasil penelitian dan pertanyaan terbuka yang diajukan salahsatu jawaban mengapa aplikasi zoom masih sering digunakan karena tampilan yang sederhana dan fitur-fitur yang ada juga tidak banyak sehingga sangat mudah untuk di gunakan, selain itu video, suara serta memasukan bahan paparan juga mudah selain dapat merekam semua aktivitas selama aplikasi digunakan.

Dalam sistem informasi pengembangan sistem serta kualitas aplikasi atau web sangat diperhatikan untuk menarik pelanggan (Stephanie et al., 2019).selain itu kualitas informasi dan kepercayaan dari pelanggan juga sangat berpengaruh terhadap kepuasan pengguna (Rakhmadian et al., 2017), terlebih lagi mahasiswa yang ada saat ini adalah mereka yang masuk dalam generasi millennial sehingga pengelola harus memperhatikan kebutuhan dan bagaimana karakteristik dari usia millennial (Hidayatullah et al., 2018). Pengembangan 
sistem yang lebih pada aplikasi zoom memang sangat mendesak seperti tingkat keamanan dan privasi dari pengguna yang masih rentan diserang hacker, sehingga dibutuhkan investasi yang lebih dalam pengembangannya. Investasi dalam suatu bisnis perlu memperhatikan peraturan atau regulasi serta tata cara yang ada sehingga investasi yang dilakukan dapat berjalan maksimal (Windhyastiti, Hidayatullah, \& Khouroh, 2019) (Windhyastiti, Hidayatullah, Khouroh, et al., 2019).

\section{SIMPULAN DAN SARAN}

Dari hasil analisis dan pembahasan diperoleh kesimpulan system quality berpengaruh positif terhadap User Satisfaction, Information Quality berpengaruh positif terhadap User Satisfaction, Service Quality berpengaruh positif terhadap User Satisfaction dan User Satisfaction berpengaruh positif terhadap Net Benefit.

\section{DAFTAR PUSTAKA}

[1] Arbie, E. (2000). Pengantar Sistem Informasi Manajemen. Edisi Ke-7, Jilid.

[2] Bernroider, E. W. N. (2008). IT governance for enterprise resource planning supported by the DeLone-McLean model of information systems success. Information and Management. https://doi.org/10.1016/j.im.2007.11.004

[3] DeLone, W. H., \& McLean, E. R. (2003). The DeLone and McLean model of information systems success: A ten-year update. Journal of Management Information Systems. https://doi.org/10.1080/07421222.2003.11045748

[4] DeLone, W. H., \& McLean, E. R. (2004). Measuring e-commerce success: Applying the DeLone and McLean Information Systems Success Model. International Journal of Electronic Commerce.

[5] Febrianto, G. (2018). The Effect of Intention to Usage to Actual Usage E-Purchasing Application. 9(12), 363-370.

[6] Hair, Jr, J. F. (2015). Essentials of Business Research Methods. In Essentials of Business Research Methods. https://doi.org/10.4324/9781315704562

[7] Hidayatullah, S., Firdiansjah, A., Patalo, R. G., \& Waris, A. (2019). The effect of entrepreneurial marketing and competitive advantage on marketing performance. International Journal of Scientific and Technology Research.

[8] Hidayatullah, S., Rachmawati, I. K., Aristanto, E., Waris, A., \& Patalo, R. G. (2020). Peran Sistem Informasi Pemasaran, Kualitas Pelayanan dan Entrepreneurial marketing serta Kepuasan Terhadap Loyalitas Generasi Milenial Berkunjung ke Tempat Wisata. https://doi.org/10.32812/jibeka.v14i1.148

[9] Hidayatullah, S., Waris, A., \& Devianti, R. C. (2018). Perilaku Generasi Milenial dalam Menggunakan Aplikasi Go-Food. JURNAL MANAJEMEN DAN KEWIRAUSAHAAN. https://doi.org/10.26905/jmdk.v6i2.2560

[10] Iivari, J. (2005). An Empirical Test of the DeLone-McLean Model of Information System Success. Data Base for Advances in Information Systems. https://doi.org/10.1145/1066149.1066152

[11]Jaafreh, A. B. (2017). Evaluation Information System Success: Applied DeLone and McLean Information System Success Model in Context Banking System in KSA. International Review of Management and Business Research.

[12] James A. O’Brien, \& Marakas, G. M. (2017). MANAGEMENT INFORMATION SYSTEMS Tenth Edition. In McGraw-Hill Irwin. 
[13] Khouroh, U., Sudiro, A., Rahayu, M., \& Indrawati, N. K. (2020). The mediating effect of entrepreneurial marketing in the relationship between environmental turbulence and dynamic capability with sustainable competitive advantage: An empirical study in Indonesian MSMEs. Management Science Letters. https://doi.org/10.5267/j.msl.2019.9.007

[14]Liao, C., Liu, Q., Kimber, D., Chiu, P., Foote, J., \& Wilcox, L. (2003). Shared interactive video for teleconferencing. Proceedings of the ACM International Multimedia Conference and Exhibition. https://doi.org/10.1145/957127.957129

[15]Mardiana, S., Tjakraatmadja, J. H., \& Aprianingsih, A. (2015). DeLone-Mclean information system success model revisited: The separation of intention to Use - Use and the integration of technology acceptance models. International Journal of Economics and Financial Issues.

[16]Mikić, I., Huang, K., \& Trivedi, M. (2000). Activity monitoring and summarization for an intelligent meeting room. Proceedings - Workshop on Human Motion, HUMO 2000. https://doi.org/10.1109/HUMO.2000.897379

[17]Ojo, A. I. (2017). Validation of the delone and mclean information systems success model. Healthcare Informatics Research. https://doi.org/10.4258/hir.2017.23.1.60

[18] Rachmawati, I. K., Handoko, Y., Nuryanti, F., Wulan, M., \& Hidayatullah, S. (2019). Pengaruh kemudahan, kepercayaan pelanggan dan kualitas informasi terhadap keputusan pembelian online. September.

[19]Rakhmadian, M., Hidayatullah, S., Respati, H., \& Malang, U. M. (2017). Analisis Kualitas Sistem Dan Kualitas Informasi Terhadap Kepuasan Pemakai Sistem Informasi Akademik Dosen. Seminar Nasional Sistem Informasi, September, 665-675.

[20]Riset, J., \& Dan, A. (2007). Sistem Informasi Manajemen. Riset Akuntansi Dan Bisnis.

[21] Saputro, P. H., Budiyanto, D., \& Santoso, J. (2016). Model Delone and Mclean Untuk Mengukur Kesuksesan E-Government Kota Pekalongan. Scientific Journal of Informatics. https://doi.org/10.15294/sji.v2i1.4523

[22] Stephanie, A., Hidayatullah, S., \& Ardianto, Y. T. (2019). An Emperical Study of Website Quality on Hotel Booking Online. 4(2), 10-14.

[23]Urbach, N., \& Müller, B. (2012). The Updated DeLone and McLean Model of Information Systems Success. https://doi.org/10.1007/978-1-4419-6108-2_1

[24]Wang, Y. S. (2008). Assessing e-commerce systems success: A respecification and validation of the DeLone and McLean model of IS success. Information Systems Journal. https://doi.org/10.1111/j.1365-2575.2007.00268.x

[25] Windhyastiti, I., Hidayatullah, S., \& Khouroh, U. (2019). How to increase city investment attraction. International Journal of Scientific and Technology Research.

[26] Windhyastiti, I., Hidayatullah, S., Khouroh, U., \& Waris, A. (2019). Role of The Online Single Submission (OSS) To Increase The City Investment Attraction. 4th INTERNATIONAL CONFERENCE OF GRADUATE SCHOOL ON SUSTAINABILITY (ICGSS) 2019, 1-6.

[27] https://www.cnnindonesia.com/teknologi/20200408124947-213-491594/penggunainternet-kala-wfh-corona-meningkat-40-persen-di-ri 